\title{
TIME SERIES ANALYSIS ABOUT THE RELATIONSHIP BETWEEN FOREIGN TRADE AND EXCHANGE RATE IN TURKISH ECONOMY
}

\author{
Bilal KARGI 1
}

DOI: 10.1515/tjeb-2015-0007

\begin{abstract}
In this study, the relationship between the foreign trade data and the exchange rate is tested using the monthly data for the period of 1992:01-2014:01 in Turkish Economy. The devaluation of local currency is expected to increase export while decreasing import rates, thus it will close the foreign trade deficit, theoretically. However, this effect is observed in varying degrees in the on both short and long terms. One of the most fundamental problems of the Turkish Economy is the foreign trade deficit, beside the Turkish Lira is a quite frequently fluctuating currency. The relationship between the foreign trade data and the exchange rate is an important topic to examine when the dependence of export to import is especially considered. In this study, the longterm relation between these two main variables and their causality are examined as using the time series analysis. Therefore, the tested hypothesis will be "there is a long term relationship between the exchange rate and the foreign trade in Turkish Economy". It is was empirically observed that this hypothesis is correct as a result of the tests. It is also observed that there is Granger causality from the exchange rate to the exports, imports and net foreign trade in addition to the fact that the long term relationship exists between the foreign trade and the rate of exchange.
\end{abstract}

Keywords:

Foreign Trade, Exchange Rate, Turkish Economy.

\section{JEL Classification: F14, F31, 024, P45.}

${ }^{1}$ PhD, Aksaray University, Turkey. 
Kargi, B. (2014).

Time Series Analysis about the Relationship between Foreign Trade and Exchange Rate in Turkish Economy

\section{Introduction}

The assumption about that international trade will maintain the economic growth has been ongoing since A. Smith. Therefore, countries try to increase their foreign trade operations by giving attention to their export amounts. However, increases in exports cause to brings about increases in imports and therefore raise the permeability of economic effects through international trade. One of the most important problems of the economies is to have foreign trade developed and deepened without giving rise to foreign trade deficit or at least to maintain this deficit up to a point that it does not interfere with the economic growth and structural development. Therefore, the factors that direct the foreign trade have been constantly researched and in particularly it is observed that there has been a concentration on the effects of the exchange rate. Bickerdike (1920) is the first academician who pointed out to the effects of the exchange rate on the foreign trade. Moreover, Marshall (1923) and Lerner (1944) gave the best-known works about the effects of relative prices. The authors mentioned that the relative prices, which intend to increase the foreign trade, are determined by exchange rates.

Although the foreign trade is known to have positive effects in the economic growth, there are also some studies in the opposite direction. The main reasons of for this are the development level of the countries, trade restriction policies like, quotas and taxes, and the international competitiveness ability together with the differences which are caused by the countries' original structures. In addition to the studies about that fact that export provides economic growth, there are many studies (Krueger, 1978; Helpman \& Krugman 1985; Grosman \& Helpman 1991) which focus on the economic growth supports supporting the export and there is a mutual causality among them. The most important factor which affects export is the exchange rate in consequence of the positive effect of exports in the growth scenario. This effect should be always taken into consideration due to the increase in demand which is caused by the effects of the exchange rate in the international prices of commodities. Furthermore, there were attempts to increase export rates are sometimes tried to be increased by creating devaluation. Narrowing the foreign trade deficit can be achieved through the increase in exports which is caused by an increase in the exchange rate (Lal \& Lowinger 2002). The expected impacts from exchange rate adjustments or currency movements (Menon, 1994; Melick, 1994) or the devaluation (Himorios, 1989) which is created to increase the exports and to narrow the foreign trade deficit is defined with J-curve in the literature. First of all, according to the curve the export dramatically decreased as the value of national currency is lowered. After a certain period of time period in which the markets adapt to the new exchange rate arrangement, the exports begin to increase and exceed above the level of pre-established arrangement period. So as to receive the expected results from the exchange rate arrangement, a certain period of time period which can differ for each from one economy to another must be experienced. (Rose \& Yellen, 1989; Backus, Kehoe, \& Kydland, 1994; Bahmani \& Ali, 2007; Yusoff, 2007).

DE GRUYTER OPEN
Timisoara Journal of Economics and Business | ISSN: 2286-0991 | www.tjeb.ro Year 2014 | Volume 7 | Issue 2 | Pages: 123-133 
Kargi, B. (2014).

Time Series Analysis about the Relationship between Foreign Trade and Exchange Rate in Turkish Economy

In today's world in which the international trade has developed and deepened, an agreement about the effects of the exchange rate on foreign trade is not reached because of the differences such as the diversity of the countries' own policies, trade volumes, tradable goods and commodities and the added values of these. Therefore the empirical studies may include differences and reach different conclusions (Lindblad \& Sellin, 2003). However, one point is almost universally accepted that uncertainties in exchange rates adversely affect the foreign trade (Pozo, 1992; Arize, Malindretos, \& Kasibhata, 2003; Chowdhury, 1993; Kenen \& Rodrik, 1986). Some studies in the literature point out that the uncertainty is considered as an opportunity by some companies (McKenzie \& Brooks, 1997; Dellas \& Zilberfarb, 1993). At the same time, there are also some studies providing the empirical evidences in the direction of that the exchange rate has no significant effect on the foreign trade (Aristotelous 2001; McKenzie 1999; Gotur, 1985). However, this ineffectiveness generally emerges in the studies which focused on bilateral trade and moreover the bilateral trade is especially made among the countries which can be listed in the developed countries category. For example, Hwaug and Lee (2005) supported the claims in the direction of this ineffectiveness for UK, on the other hand Dash and Narasimhan (2011) mentioned about a full transition from the exchange rate to the export for India as an emerging economy. Therefore, it would be true to say that the most important factor determining the interaction between the exchange rate and the export is the development levels of each country that do undergoes an activity such as trade (Taylor \& Sarno, 1998). The relative stability in the developed countries reduces the uncertainties. On the other hand risk affects the foreign trade adversely. The exchange rate uncertainties cause the rising costs for the entrepreneurs who avoid the risks (Hooper \& Kohlhagen 1978). But at the same time, the export provides the new abilities, technologies, experiences and information for the entrepreneurs (Giles \& Williams, 2000; Porter 1990). Many empirical studies were conducted through these theoric discussions. In this study, the results that were obtained by studies which focused on the selected country and selected country groups are presented basically succintly/ briefly. A study is conducted about the Turkish economy with time series analysis method which is also utilized for many of the studies in this literature. Therefore, a conclusion is tried to be reached about the exchange rate's long term effects on the foreign trade in the Turkish Economy.

\section{Literature}

Through this theoretical framework, findings which are obtained by some selected empirical studies that are associated with the relationship between foreign trade and exchange rate, which has a quite vast literature, are presented in Table1.

DE GRUYTER OPEN
125

Timisoara Journal of Economics and Business | ISSN: 2286-0991 | www.tjeb.ro Year 2014 | Volume 7 | Issue 2 | Pages: 123-133 
Kargi, B. (2014).

Time Series Analysis about the Relationship between Foreign Trade and Exchange Rate in Turkish Economy

Table 1. Selected Studies for Selected Country/ Country Groups

\begin{tabular}{|c|c|c|c|}
\hline Authors & Period & Country/Countries & Findings \\
\hline $\begin{array}{l}\text { Arize, Osang and Slottje } \\
(2000)\end{array}$ & $1973-1996$ & $\begin{array}{l}13 \\
\text { Underdeveloped }\end{array}$ & $\begin{array}{l}\text { Uncertainty and volatility in exchange rates are } \\
\text { effective on export demand in the short and long term. }\end{array}$ \\
\hline $\begin{array}{l}\text { Kasman } \\
\text { and Ayhan (2008) }\end{array}$ & $1982-2005$ & Turkey & $\begin{array}{l}\text { Foreign exchange reserves are effective on exchange } \\
\text { rates in the short and long-term. Casualty exists out of } \\
\text { reserves in the direction of exchange rates. }\end{array}$ \\
\hline Cheung et al. (2009) & 1986-2008 & China & Exchange rate is effective on trade deficit. \\
\hline $\begin{array}{l}\text { Appuhamilage } \\
\text { and Alhayky (2010) }\end{array}$ & 1993-2007 & Sri Lanka-China & $\begin{array}{l}\text { Exchange rate volatility not only takes a significant role } \\
\text { on bilateral trade but also is effective on sectorial } \\
\text { trade. }\end{array}$ \\
\hline Drama et al. (2010) & $1975-2007$ & Cote d'Ivoire & $\begin{array}{l}\text { Exchange rate has significant positive effects on trade } \\
\text { balance. }\end{array}$ \\
\hline Di Nino et al. (2011) & $1892-2011$ & Italy & $\begin{array}{l}\text { Rate adjustment has positive effects especially on } \\
\text { export in manufacturing industry and high-productivity } \\
\text { sectors. }\end{array}$ \\
\hline Nassif et al. (2011) & $1999-2010$ & Brazil & Trade balance requires an optimum exchange rate. \\
\hline $\begin{array}{l}\text { Hsing } \\
\text { and Guisan (2011) }\end{array}$ & 1970-2009 & Spain & Exchange rate effective in reducing the trade deficit. \\
\hline Xiangquan et al. (2011) & $1978-2007$ & China & $\begin{array}{l}\text { Exchange rate has consistant and positive effects on } \\
\text { export growth. }\end{array}$ \\
\hline Fogarasi (2011) & $1999-2008$ & Hungary & $\begin{array}{l}\text { Exchange rate fluctuations have a significant positive } \\
\text { effect on agricultural trade. }\end{array}$ \\
\hline Savoiu et al. (2012) & $\begin{array}{l}1929-1938 \\
2001-2010\end{array}$ & Romania & $\begin{array}{l}\text { During periods of crisis and stagnation, effects of } \\
\text { exchange rates on trade can be strongly seen. }\end{array}$ \\
\hline $\begin{array}{l}\text { Bahmani-Oskooee } \\
\text { and Gelan (2012) }\end{array}$ & 1971-2008 & Africa Countries & $\begin{array}{l}\text { J-curve is valid and exchange rate causes exports to } \\
\text { rise. }\end{array}$ \\
\hline $\begin{array}{l}\text { Müller-Plantenberg } \\
\text { (2012) }\end{array}$ & 1980s & $\begin{array}{l}9 \text { Selected } \\
\text { Countries }\end{array}$ & $\begin{array}{l}\text { Exchange rate fluctuations which are disrupted after } \\
\text { the economic shocks adversely affect the foreign } \\
\text { trade deficit. }\end{array}$ \\
\hline Shahbaz et al. (2012) & 1980-2006 & Pakistan & Exchange Rate is effective on trade in long-term. \\
\hline $\begin{array}{l}\text { Kafle } \\
\text { and Kennedy (2012) }\end{array}$ & $1970-2010$ & OECD and US & $\begin{array}{l}\text { Exchange rate volatility has a meaningful negative } \\
\text { effect on total trade (export + import). }\end{array}$ \\
\hline Sheng et al. (2012) & $1998-2007$ & East Asian & $\begin{array}{l}\text { Integration in the region has created negative effects } \\
\text { on exchange rate and foreign trade. }\end{array}$ \\
\hline Sweidan (2013) & 1976-2009 & Jordan & $\begin{array}{l}\text { Devaluation has no effects to increase export in short- } \\
\text { term due to its disrupting nature. }\end{array}$ \\
\hline Baek (2013) & $1991-2010$ & Korea-Japan & $\begin{array}{l}\text { Korea's foreign trade is more sensitive to bilateral } \\
\text { trade than Japan's. }\end{array}$ \\
\hline
\end{tabular}

DE GRUYTER OPEN
Timisoara Journal of Economics and Business | ISSN: 2286-0991 | www.tjeb.ro

Year 2014 | Volume 7 | Issue 2 | Pages: 123-133 
Kargi, B. (2014).

Time Series Analysis about the Relationship between Foreign Trade and Exchange Rate in Turkish Economy

\begin{tabular}{|c|c|c|c|}
\hline Authors & Period & Country/Countries & Findings \\
\hline $\begin{array}{l}\text { Bahmani-Oskooee } \\
\text { and Zhang (2013) }\end{array}$ & $1978-2010$ & UK-China & $\begin{array}{l}\text { The rates in China is effective in bilateral trade in } \\
\text { short-term however the degree of its effect is limited in } \\
\text { long-term. }\end{array}$ \\
\hline Berg (2013) & $1980-2007$ & OECD & $\begin{array}{l}10 \% \text { shrinking of stocks will increase trade deficit by } \\
0.3 \% \text { after } 2 \text { years. }\end{array}$ \\
\hline Sheldon et al. (2013) & 1976-1999 & 26 Countries & $\begin{array}{l}\text { Exchange rate uncertainties are negatively effective } \\
\text { on the fresh fruits and vegetables trade. }\end{array}$ \\
\hline $\begin{array}{l}\text { Yusoff } \\
\text { and Fabrina (2014) }\end{array}$ & 1970-2009 & Indonesia & Exchange rate consistency affects trade and growth. \\
\hline $\begin{array}{l}\text { Bahmani-Oskooee } \\
\text { and Harvey (2014) }\end{array}$ & $1973-2011$ & USA-Indonesia & $\begin{array}{l}\text { Exchange rate is effective in bilateral trade mostly on } \\
\text { industrial goods trade. }\end{array}$ \\
\hline Niroomand et al. (2014) & $1980-2011$ & $\begin{array}{l}\text { Developing } \\
\text { Countries }\end{array}$ & $\begin{array}{l}\text { Trade deficit has effective on financial markets in the } \\
\text { short and long-term. }\end{array}$ \\
\hline
\end{tabular}

As can be seen in the literature review, although all the studies do not obtain not all studies reach the same results, an overall review is considered showing that exchange rate fluctuations have negative impacts on foreign trade. This relation is stronger especially in developing countries. Furthermore the reason of for this is indicated indicates that exchange rate fluctuations in developed countries are not so sharp and the stability of exchange rates is relatively better. Then exchange rate stability builds stability Then, the exchange rate stability is built on foreign trade balance as well. However developing countries implement policy preferences associated with foreign exchange reserves and rate movements in order to reduce foreign trade deficits. The exchange rate stability builds a relative consistency in particularly to foreign trade in bilateral trade in developed countries; on the other hand exchange rate fluctuations in the developing countries may also cause fluctuations in the foreign trade.

\section{Data and Method}

Monthly data of Turkish economy for the period of 1992:01-2014:01 are used in the study. Data sets are obtained through CBRT-EDDS (Central Bank of the Republic of Turkey - Electronic Data Delivery System). Foreign trade data are dominated in U.S. Dollars. Seasonal effects are eliminated from the series. Variables are set as export (EXP), import (IMP), net foreign trade (NFT) and exchange rate (X-RATE). Seasonal effects are also eliminated from the variables.

The analyses regarding the relationship between exchange rate and foreign trade are performed in two stages. In the first stage co-integration tests are applied in order to determine long-term relations of variables. Therefore, ADF (Dickey \& Fuller, 1979), PP (Phillips \& Perron, 1988) and

\section{DE GRUYTER OPEN}


Kargi, B. (2014).

Time Series Analysis about the Relationship between Foreign Trade and Exchange Rate in Turkish Economy

KPSS (Kwiatkowski et al., 1992) unit-root tests are applied. The co-integration relation is investigated by applying the two stages EG test (Engle \& Granger, 1987) and JJ (Johansen \& Juselius, 1990) test with the series which are stationary series from the same order. In the second stage, Granger (1969) causality tests were applied in order to determine the causality aspect of long-term relations.

\section{Empirical Findings}

Series are held subject to unit-root tests in order to determine long-term relations in the first stage of the analysis. Data needs to be stationary in the same order for co-integration tests associated with long-term relation. Table 2 demonstrates the results of unit root tests conducted. Persistence models and trend models are used for each unit root test.

Table 2. ADF, PP and KPSS Unit Root Tests

\begin{tabular}{lllllll}
\hline & \multicolumn{1}{c}{ ADF } & \multicolumn{1}{c}{ ADF $\Delta$} & \multicolumn{1}{c}{ PP } & \multicolumn{1}{c}{ PP $\Delta$} & \multicolumn{1}{c}{ KPSS } & \multicolumn{1}{c}{ KPSS $\Delta$} \\
\hline \multirow{2}{*}{ NFT } & -1.743797 & -23.59615 & -2.321692 & -23.73139 & 1.619323 & 0.025532 \\
& $(-2.872328)$ & $(-2.872328)$ & $(-2.872286)$ & $(-2.872328)$ & $(0.463000)$ & $(0.463000)$ \\
EXP & 0.560562 & -5.535716 & -0.434323 & -33.02147 & 1.979967 & 0.223033 \\
& $(-2.872811)$ & $(-2.872811)$ & $(-2.872286)$ & $(-2.872328)$ & $(0.463000)$ & $(0.463000)$ \\
IMP & 0.309682 & -5.003180 & -0.572546 & -22.62847 & 1.911751 & 0.082308 \\
& $(-2.872950)$ & $(-2.872950)$ & $(-2.872286)$ & $(-2.872328)$ & $(0.463000)$ & $(0.463000)$ \\
\multirow{4}{*}{ X-RATE } & -0.115006 & -10.64070 & -0.193269 & -11.15152 & 1.913450 & 0.098810 \\
& $(-2.872370)$ & $(-2.872370)$ & $(-2.872286)$ & $(-2.872328)$ & $(0.463000)$ & $(0.463000)$ \\
\hline
\end{tabular}

Note: Values in brackets are critical values for significance level of $5 \%$ for each 3 tests.

According to the results which are shown in Table 2, all the series level values contain unit-root. However when primary differences of series are taken, they became stationary. In this case, the long-term relation is convenient to be investigated since all the series are stationary at the same order.

In order to determine the long-term co-integration relation, two different tests are applied. The first of these is "two stage Engle-Granger Co-integration" test. This test It aims at testing the hypothesis according to which two variables forming regression are co-integrated as at level values of error terms to be obtained through regression model to be created between the two variables. The results which are obtained through the tests are shown in Table 3.

DE GRUYTER OPEN
Timisoara Journal of Economics and Business | ISSN: 2286-0991 | www.tjeb.ro Year 2014 | Volume 7 | Issue 2 | Pages: 123-133 
Kargi, B. (2014).

Time Series Analysis about the Relationship between Foreign Trade and Exchange Rate in Turkish Economy

Table 3. Engle- Granger Cointegration Test

\begin{tabular}{ccccc}
\hline Equation & Coefficient & t-Stat. & $\mathrm{u} \rightarrow$ ADF & $\mathrm{u} \rightarrow$ PP \\
\hline $\mathrm{nft}=\mathrm{f}(\mathrm{x}-$ rate $)$ & -1978.018 & -12.78087 & $\begin{array}{r}-2.691873 \\
(-1.942035)\end{array}$ & $\begin{array}{l}-3.582010 \\
(-1.942031)\end{array}$ \\
\cline { 2 - 5 } $\mathrm{exp}=\mathrm{f}(\mathrm{x}-$ rate) & 4969.397 & 21.85676 & $\begin{array}{r}-1.773062^{*} \\
(-1.942035)\end{array}$ & $\begin{array}{l}-2.071940 \\
(-1.942031)\end{array}$ \\
\cline { 2 - 5 } $\mathrm{imp=f(x-rate)}$ & -6947.414 & -18.94386 & $\begin{array}{r}-2.195405 \\
(-1.942089)\end{array}$ & $\begin{array}{l}-2.342275 \\
(-1.942031)\end{array}$ \\
\cline { 2 - 5 } $\mathrm{nft}=\mathrm{f}(\mathrm{x}$-rate) & -1978.018 & -12.78087 & $\begin{array}{r}-2.691873 \\
(-1.942035)\end{array}$ & $\begin{array}{l}-3.582010 \\
(-1.942031)\end{array}$ \\
\hline
\end{tabular}

Note: The values in brackets and under the coefficients are Standard Deviation Values. The values in brackets and under ADF, PP and KPSS test statistics are the critical values for $5 \%$ meaning level.

$\left(^{*}\right)$ Although (*) It is not stationary in the level of $5 \%$, it is stationary in the level of $1 \%$.

According to the created regression models, net foreign trade, export and import variables are taken as the individual dependent variables and the exchange rate variable, of which the effects over each of them is investigated, is taken as independent variable. ADF and PP tests applied on the error terms which are created from the results that are obtained through these 3 regressions and the error terms are seen to be stationary as of their level values. ADF and PP tests for each 3 regression are realized for $5 \%$ significance level. Solely, ADF test result of error terms of export $=\mathrm{f}($ rate) regression is seen to be stationary with its $1 \%$ significance level. Thus the variables are seen to be co-integrated in the long-term as of EG two stage test results.

The second test which is used in order to investigate the long-term relation is the $\mathrm{JJ}$ test. The results which are obtained by this test which is used to investigate whether variables in regression models to be created with more than two variables would have co-integrating vectors or not, are shown in Table 4.

Table 4. Johansen- Juselius Cointegration Test

\begin{tabular}{llllrrc}
\hline $\mathrm{H}_{0}$ & $\mathrm{H}_{1}$ & Eigenvalue & Trace Stat. & 0,05 & Max-Eigen Stat. & 0,05 \\
\hline$r=0$ & $r \geq 1$ & 0.116647 & 44.95628 & 35.19275 & 32.49600 & 22.29962 \\
$r=1$ & $r \geq 2$ & 0.033611 & 12.46028 & 20.26184 & 8.957407 & 15.89210 \\
$r=2$ & $r \geq 3$ & 0.013281 & 3.502873 & 9.164546 & 2.502873 & 9.164546 \\
\hline
\end{tabular}

According to Table 4 showing results of $\mathrm{JJ}$ tests performed through persistent and non-trend model, there are at least 1 vector to co-integrate exchange rate, export and import variables in the long-term. As long as Trace statistics in Table 4 are larger than the critical value of 0.05 , this result

DE GRUYTER OPEN
Timisoara Journal of Economics and Business | ISSN: 2286-0991 | www.tjeb.ro

Year 2014 | Volume 7 | Issue 2 | Pages: 123-133 
Kargi, B. (2014).

Time Series Analysis about the Relationship between Foreign Trade and Exchange Rate in Turkish Economy

will be attained. The same result is also obtained through comparing Max-Eigen statistics with the critical value of 0.05 .

The results of Granger Causality test for these variables which have long-term relations amongst are shown in Table 5.

Table 5. Granger Causality Test

\begin{tabular}{llll}
\hline Hypotheses & Chi-sq & Prob. & Result \\
\hline X-RATE does not Granger Cause EXP & 3.94557 & 0.02052 & Hypothesis accepted \\
\cline { 2 - 4 } X-RATE does not Granger Cause IMP & 5.04086 & 0.00712 & Hypothesis accepted \\
\cline { 2 - 4 } X-RATE does not Granger Cause NFT & 3.33659 & 0.03710 & Hypothesis accepted \\
\cline { 2 - 4 } EXP does not Granger Cause NFT & 9.42986 & 0.00011 & Hypothesis accepted \\
\hline
\end{tabular}

It is seen in Table 5 that the causality is identified from exchange rate to export, from exchange rate to import and from exchange rate to net foreign trade direction. At the same time, the causality from export to net foreign trade and from import to net foreign trade is identified. Only one-directional causality is identified between exchange rate and export, import and net foreign trade.

\section{Conclusion}

One of the most essential problems of Turkish economy is foreign trade deficit. One of the most basic reasons of this is high energy import and the other is to have export operations based on import. In spite of export which does not have high added value, especially continuous increase in import of consumer goods had given continuity to foreign trade deficit and turned this into a chronic problem. Along with policies of governments encouraging export, exchange rate policies including devaluations have been applied as the policies which are aiming to solve this chronic problem. However, since structural arrangements could not be implemented, trade deficit maintains existence as a chronic problem due to the two specified basic problems. The hypothesis "exchange rate is effective on foreign trade" tested with this study and is accepted empirically, therefore two basic conclusions are obtained. The first of these is that exchange rate and export, import and net foreign trade are co-integrated in the long-term. This conclusion is attained at the results of two separate tests. Moreover, the second significant conclusion is that there is onedirected causality from exchange rate to export, import and net foreign trade. In addition to these two basic conclusions, one-directed causality is to be under consideration from both export and import towards net foreign trade.

DE GRUYTER OPEN
Timisoara Journal of Economics and Business | ISSN: 2286-0991 | www.tjeb.ro Year 2014 | Volume 7 | Issue 2 | Pages: 123-133 
Kargi, B. (2014).

Time Series Analysis about the Relationship between Foreign Trade and Exchange Rate in Turkish Economy

\section{References}

Appuhamilage, K. S. A., \& Alhayky, A. A. A. (2010). Exchange rate movements' effect on Sri Lanka-China trade. Journal of Chinese Economic and Foreign Trade Studies, 3(3), 254-267.

Aristotelous, K. (2001). Exchange-rate volatility, exchange-rate regime and trade volume: Evidence from the UK-US export function (1989-1999), Economic Letters, 72, 87-89.

Arize, A. C., Malindretos J., \& Kasibhata, K. M. (2003). Does exchangerate volatility depress export flows: The case of LDC's. International Advances in Economic Research, 9(1), 7-19.

Arize, A. C., Osang, T., \& Slottje, D. J. (2000). Exchange-rate volatility and foreign trade: Evidence from thirteen LDC's. Journal of Business and Economic Statistics, 18(1), 10-17.

Backus, D. K., Kehoe, P.J. \& Kydland, F. E. (1994). Dynamics of the trade balance and the terms of trade: The J Curve. American Economic Review, 84(1), 84-103.

Baek, J. (2013). Does the exchange rate matter to bilateral trade between Korea and Japan? Evidence from Commodity Trade Date. Economic Modelling, 30, 856-862.

Bahmani-Oskooee, M., \& Ali, M. K. (2007). The J-Curve in the emerging economies of Eastern Europe. The International Trade Journal, 19, 165-178.

Bahmani-Oskooee, M., \& Gelan, A. (2012). Is there J-Curve effect in Africa?. International Review of Applied Economics, 26(1), 73-81.

Bahmani-Oskooee, M., \& Harvey, H. (2014). US-Indonesia trade at commodity level and the role of the exchange rate. Applied Economics, 46(18), 2154-2166.

Bahmani-Oskooee, M., \& Zhang, R. (2013). The J-Curve: Evidence from commodity trade between UK and China. Applied Economics, 45(31), 4369-4378.

Berg, T. O. (2013). Cross-country evidence on the relation between stock prices and the current account. Applied Economics, 45(16), 2267-2277.

Bickerdike, C. F. (1920). The instability of foreign exchange. Economic Journal, 30, 118-122.

Cheung, Y-W., Chinn, M. D., \& Fujii, E. (2009). China's current account and exchange rate. CESifo Working Paper, No.2587.

Chowdhury, A. R. (1993). Does exchange rate volatility depress trade flows? Evidence from error-correction models. Review of Economics and Statistics, 75(4), 700-706.

Dash, A. K., \& Narasimhan, V. (2011). Exchange rate pass-through: How much do exchange rate changes affect the prices of Indian exports and imports. South Asia Economic Journal, 12(1), 1-23.

Dellas, H., \& Zilberfarb, B-Z. (1993). Real exchange rate volatility and international trade: A re-examination of the theory. Southern Economic Journal, 59(4), 641-647.

Dickey, D. A., \& W. A. Fuller. (1979). Distribution of the estimators of autoregressive time series with a unit root. Journal of the American Statistical Association, 74, 427-431.

Di Nino, V., Eichengreen, B., \& Sbracia, M. (2011). Real exchange rates, trade, and growth: Italy 1861-2011. Banca D'Italia, Economic History Working Papers, No.10.

Drama, B. G. H. (2010). The effects of real exchange rate on trade balance in Cote d'Ivoire: Evidence from the cointegration analysis and error-correction models. MPRA Paper, No.21810.

Engle, R. F., \& Granger, C. W. J. (1987). Co-integration and errors correction: Representation, estimation, and testing. Econometrica, 55(2), 251-276.

DE GRUYTER OPEN 
Kargi, B. (2014).

Time Series Analysis about the Relationship between Foreign Trade and Exchange Rate in Turkish Economy

Fogarasi, J. (2011). The effect of exchange rate volatility upon foreign trade of Hungarian agricultural products. Studies in Agricultural Economics, 113(1), 85-96.

Giles J. A., \& Williams C. L. (2000). Export-led growth: A survey of the empirical literature and some non-causality results part 1 . The Journal of International Trade and Economic Development, 9(3), 261-337.

Gotur, P. (1985). Effects of exchange rate volatility on trade: Some further evidence. IMF Staff Papers, 32(3), 475-512.

Granger, C. W. J. (1969). Investigating causal relations by econometric models and crossspectral methods. Econometrica, 37(3), 424-438.

Grossman, G., \& Helpman, E. (1991). Innovation and growth in the global economy, Cambridge: MIT Press.

Helpman, E., \& Krugman, P. (1985). Market structure and foreign trade, Cambridge: MIT Press.

Himarios, D. (1989). Do devaluation improve the trade balance? The evidence revisited. Economic Inquiry, 27(1), 143-168.

Hooper, P., \& Kohlhagen, S. (1978). The effect of exchange rate uncertainty on the price and volume of international trade. Journal of International Economics, 8(4), 483-511.

Hsing, Y., \& Guisan, M. C. (2011). Real exchange rate, foreign trade and real output growth: The case of Spain, 1970-2009. Applied Econometrics and International Development, 11(1), 47-58.

Hwang, H., \& Lee, J. (2005). Exchange rate volatility and trade flows of the U.K. in 1990's. International Area Studies Review, 8(1), 173-182.

Johansen, S., \& Juselius, K. (1990). Maximum likelihood estimation and inference on cointegration with applications to the demand for money. Oxford Bulletin of Economics and Statistics, 53, 169-210.

Kafle, K. R., \& Kennedy, P, L. (2012). Exchange rate volatility and bilateral agricultural trade flows: The case of the United States and OECD Countries. Southern Agricultural Economics Association 2012 Annual Meeting, February 4-7, Birmingham, Alabama.

Kasman, A., \& Ayhan, D. (2008). Foreign exchange reserves and exchange rates in Turkey: Structural breaks, unit roots and cointegration. Economic Modelling, 25, 83-92.

Kenen, P., \& Rodrik, D. (1986). Measuring and analyzing the effects of short term volatility on real exchange rates. Review of Economics and Statistics, 68(2), 311-315.

Krueger, A. (1978). Foreign trade regimes and economic development: Liberalisation attempts and consequences, Cambridge: Ballinger.

Kwiatkowski, D., Phillips, P. C. B., Schmidt, P., \& Shin, Y. (1992). Testing the null hypothesis of stationary against the alternative of a unit root. Journal of Econometrics, 54, 159178.

Lal, A.K., \& Lowinger, T. C. (2002). Nominal effective exchange rate and trade balance adjustment In South Asia Countries. Journal Of Asian Economics, 13(3), 371-383.

Lerner, A. (1944). The economics of control, New York: Macmillan.

Lindblad, H., \& Sellin, P. (2003). The equilibrium rate of unemployment and the real exchange rate: An unobserved components system approach. Riskbank Research Paper Series, No.52.

Marshall A. (1923). Money, credit and commerce, London: Macmillan.

McKenzie, M. D. (1999). The impact of exchange rate volatility on international trade flows. Journal of Economic Surveys, 13(1), 71-106.

\section{DE GRUYTER} OPEN 
Kargi, B. (2014).

Time Series Analysis about the Relationship between Foreign Trade and Exchange Rate in Turkish Economy

Mckenzie, M. D., \& Brooks, R. D. (1997). The impact of exchange rate volatility on GermanU.S. trade flows. Journal of International Financial Markets Institutions and Money, 7(1), 73-87.

Melick R. (1994). Aggregate exchange rate pass-through: Instability and inference. Journal of Economic Integration, 9(4), 427-443.

Menon J. (1994). Exchange rates and prices of Australian manufactured exports. Weltwirtschaftliches Archive, 128(4), 695-710.

Müller-Plantenberg, N. A. (2012). Boom-and-bust cycles marked by capital inflows, current account deterioration and a rise and fall of the real exchange rate. Universidad Autonoma de Madrid, Working Papers in Economic Theory, No.10.

Nassif, A., Feijo, C., \& Araujo, E. (2011). The trend of the real exchange rate overvaluation in open emerging economies: The case of Brazil. Textos Para Discussao Uff/Economia, 272, 1-53.

Niroomand, F., Hajilee, M., \& Al Nasser, O. M. (2014). Financial market development and trade openness: Evidence from emerging economies. Applied Economics, 46(13), 1490-1498.

Phillips, P. C. B., \& Perron, P. (1988). Testing for an unit root in time series regression. Biometrika, 75, 335-346.

Porter, M. E. (1990). The competitive advantage of nations, New York: The Free Press.

Pozo, S. (1992). Conditional exchange-rate volatility and the volume of international trade: Evidence from the early 1900's. Review of Economics and Statistics, 74(2), 325-329.

Rose, A. K., \& Yellen, J. L. (1989). Is there a J-curve?. Journal of Monetary Economics, 24, 5368.

Savoiu, G., Dinu, V., \& Tachiciu, L. (2012). Romania foreign trade in global recession, revealed by the extended method of exchange rate indicators. Economic Interferences, 14(31), 173-194.

Shahbaz, M, Jalil, A., \& Islam, F. (2012). Real exchange rate changes and the trade balance: The evidence from Pakistan. The International Trade Journal, 26, 139-153.

Sheng, A., Teng, K. K., \& Wai, C. C. (2012). Patterns of exchange rates and current accounts: The East Asian waltz. Singapore Economic Review, 57(2), 1-34.

Sheldon, I., Mishra, S. K., Pick, D., \& Thompson, S. E. (2013). Exchange rate uncertainty and US bilateral fresh fruit and fresh vegetable trade: An application of the gravity model. Applied Economics, 45(15), 2067-2082.

Sweidan, O. D. (2013). The effect on exchange rate on exports and imports: The case of Jordan. The International Trade Jourdan, 27, 156-172.

Taylor, M., \& Sarno, L. (1998). The behavior of real exchange rates during the post-Bretton Woods period. Journal of International Economics, 46(2), 281-312.

Xiangquan, Z., Yuxue, C., Shisong, Q., \& Yumei, Y. (2011). Real exchange rate, foreign trade and employment: Evidence from China. IZA Discussion Paper Series, No. 5931.

Yusoff, M. B. (2007). The Malaysian real trade balance and the real exchange rate. International Review of Applied Economics, 21(5), 655-667.

Yusoff, M. B., \& Febrina, I. (2014). Trade openness, real exchange rate, gross domestic investment and growth in Indonesia. The Journal of Applied Economic Research, 8(1), 1-13. 